Article

\title{
Highly Graphitic Carbon Nanofibers Web as a Cathode Material for Lithium Oxygen Batteries
}

\author{
Hyungkyu Han ${ }^{1}$, Yeryung Jeon ${ }^{2}$, Zhiming Liu ${ }^{2}$ and Taeseup Song ${ }^{2, *(\mathbb{D})}$ \\ 1 Regional Centre of Advanced Technologies and Materials, Department of Physical Chemistry, \\ Faculty of Science, Palacky University, Slechtitelu 11, 78371 Olomouc, Czech Republic; \\ hyungkyu85@gmail.com \\ 2 Department of Energy Engineering, Hanyang University, Seoul 133-791, Korea; jeonye8753@gmail.com (Y.J.); \\ skyandsealiu@gmail.com (Z.L.) \\ * Correspondence: tssong@hanyang.ac.kr
}

Received: 20 December 2017; Accepted: 25 January 2018; Published: 31 January 2018

\begin{abstract}
The lithium oxygen battery is a promising energy storage system due to its high theoretical energy density and ability to use oxygen from air as a "fuel". Although various carbonaceous materials have been widely used as a cathode material due to their high electronic conductivity and facial processability, previous studies mainly focused on the electrochemical properties associated with the materials (such as graphene and carbon nanotubes) and the electrode configuration. Recent reports demonstrated that the polarization associated with cycling could be significantly increased by lithium carbonates generated from the reaction between the carbon cathode and an electrolyte, which indicates that the physicochemical properties of the carbon cathode could play an important role on the electrochemical performances. However, there is no systematic study to understand these phenomena. Here, we systematically explore the electrochemical properties of carbon nanofibers (CNF) webs with different graphitization degree as a cathode for Li oxygen batteries. The physicochemical properties and electrochemical properties of CNF webs were carefully monitored before and after cycling. CNF webs are prepared at 1000, 1200 and $1400{ }^{\circ} \mathrm{C}$. CNF web pyrolyzed at $1400{ }^{\circ} \mathrm{C}$ shows lowered polarization and improved cycle retention compared to those of CNF webs pyrolyzed at 1000 and $1200^{\circ} \mathrm{C}$.
\end{abstract}

Keywords: carbon nanofibers; electrospinning; lithium oxygen batteries

\section{Introduction}

Development of new energy storage systems with a high energy density beyond $\mathrm{Li}$ ion batteries is essential to the critical applications such as large-scale storage for renewable power sources, electric vehicles, and plug-in hybrid electric vehicles $[1,2]$. $\mathrm{Li}-\mathrm{O}_{2}$ batteries have received significant attention as a promising energy storage system due to their higher energy density $\left(\sim 3500 \mathrm{Wh} \cdot \mathrm{kg}^{-1}\right)$ than conventional $\mathrm{Li}$ ion batteries and simple concept [3,4]. However, their poor electrochemical properties, caused by the electrolyte instability, a large polarization upon both oxygen reduction reaction (ORR) and oxygen evolution reaction (OER) and pore clogging of cathode by the discharge product $\left(\mathrm{Li}_{2} \mathrm{O}_{2}\right)$, limit their practical use $[5,6]$.

Various materials and structures on the cathode have been intensively explored to overcome these problems [7-11]. Many kinds of carbonaceous materials, including carbon black, single/multi-walled carbon nanotubes, graphene and reduced graphene oxide, have been intensively explored as a cathode material due to their high electronic conductivity and facile processability [12-15]. The pore size and volume in the carbonaceous materials based cathode were engineered to provide a large tri-phase (solid-liquid-gas) regions for oxygen reduction and prevent the pore clogging associated with $\mathrm{Li}_{2} \mathrm{O}_{2}$ discharge product [16]. Recent reports demonstrated that the carbon cathode reacts with $\mathrm{Li}_{2} \mathrm{O}_{2}$ and 
this reaction results in the formation of lithium carbonates film on the surface of carbon cathode, which significantly increases the charge polarization [3,17-21]. To decrease polarization associated with formation/decomposition of $\mathrm{Li}_{2} \mathrm{O}_{2}$, various transition metal oxides and novel metals have been explored as a catalyst [5,22-24]. Although it is generally accepted that the electrocatalyst could enhance the kinetics associated with formation/decomposition of $\mathrm{Li}_{2} \mathrm{O}_{2}$, their catalytic activity should be investigated in the stable electrolyte system to understand their substantive effectiveness and underlying mechanism. Regarding the catalytic effect of carbonaceous materials itself during the cycling, it is certain that carbon materials play an important role in electrochemical performances. Therefore, it is expected that the physicochemical properties and geometry of carbon based cathode could significantly affect upon the electrochemical performances. However, there is no systematic study to understand the effect of physicochemical properties of carbon cathode on the electrochemical performances, which is critical to improve the performances of Li-oxygen batteries.

Here, we systematically study the electrochemical properties of carbon nanofibers (CNF) webs with different graphitization degree as a cathode for Li oxygen batteries. CNF webs are simply prepared using electrospinning method, and its graphitization degree was controlled by adjusting pyrolysis temperature $[25,26]$. The three dimensional network structure of CNF web enables an efficient electron transport along one dimensional geometry and provides uniform pore structure [27]. The geometrical advantages of CNF webs allow us to investigate the influence of graphitization degree on the electrochemical performances without its degradation caused by the pore clogging associated with $\mathrm{Li}_{2} \mathrm{O}_{2}$. The physicochemical properties and electrochemical properties of CNF webs were carefully monitored before and after cycling. The CNF web shows different electrochemical properties as a function of the graphitization degree. The CNF web with high graphitization degree exhibits the low polarization during OER/ORR reactions and improved cycle performance compared to those of the CNF webs with lower graphitization degree. These improvements could be attributed to the enhanced chemical stability came from the high graphitization degree.

\section{Experimental Section}

\subsection{Preparation of Carbon Nanofibers Air Electrode}

Carbon nanofibers were synthesized using electrospinning. Polyacrylonitrile (PAN, Mw $\approx 150,000$, Sigma Aldrich, St. Louis, MO, USA) was dissolved in DMF to form a $10 \mathrm{wt} \%$ solution. The prepared solutions were mixed using a magnetic stirrer at $60{ }^{\circ} \mathrm{C}$ for $2 \mathrm{~h}$. Then, the prepared solutions were transferred into a $20 \mathrm{~mL}$ syringe with an 18-gauge metal nozzle made of stainless steel. The solution was electrospun at a DC voltage of $\sim 20 \mathrm{kV}$ and a flow rate of $0.5 \mathrm{~mL} \cdot \mathrm{h}^{-1}$. The metallic current collector was placed $\sim 10 \mathrm{~cm}$ below the tip of the nozzle to collect the nanofibers. The as-spun nanofibers were stabilized at $250^{\circ} \mathrm{C}$ for $1 \mathrm{~h}$ in air atmosphere to induce dimensional stability of the carbon nanofibers. Then, carbon nanofibers were obtained by the calcination of as-spun nanofibers in argon atmosphere at $1000{ }^{\circ} \mathrm{C}, 1200^{\circ} \mathrm{C}$, and $1400^{\circ} \mathrm{C}$ for $1 \mathrm{~h}$.

\subsection{Characterization}

Carbon nanofibers electrodes were characterized using a field emission scanning electron microscope (FE-SEM, JEOL JSM-7600F, JEOL, Tokyo, Japan) and X-ray diffraction (XRD, Rigaku D/MAX RINT-2000, Rigaku, Tokyo, Japan).

\subsection{Evaluation of Electrochemical Properties}

A Swagelok-type Li air cell was assembled using the carbon nanofibers cathode together with a $\mathrm{Li}$ anode and glass fibre separator (GF/D, Whatman, Maidstone, UK). 1.0 M LiTFSi in TEGDME was used as the electrolyte. Assembling of the Swagelok-type cells was carried out in an argon glove box. After the sealed cells were removed from the argon glove box, the cathode side was exposed to a pressure balanced 
chamber filled with $1 \mathrm{~atm}$ dry $\mathrm{O}_{2}$ gas $\left(<3\right.$ ppm $\left.\mathrm{H}_{2} \mathrm{O}\right)$. The Swagelok-type cells were cycled between $2.5 \mathrm{~V}$ and $4.5 \mathrm{~V}$ using a battery cycle tester (TOSCAT 3000, Toyo Systems, Tokyo, Japan).

\section{Results and Discussion}

Figure 1 shows electron microscope images of CNFs webs synthesized at $1000{ }^{\circ} \mathrm{C}(\mathrm{CNF} 1000)$, $1200{ }^{\circ} \mathrm{C}(\mathrm{CNF} 1200)$ and $1400{ }^{\circ} \mathrm{C}(\mathrm{CNF} 1400)$. The CNFs have uniform diameter ranging from $350 \mathrm{~nm}$ to $450 \mathrm{~nm}$ regardless of the pyrolysis temperature. However, their morphologies were significantly influenced by the processing temperature. The CNFs become wavy from straight morphology as increasing pyrolysis temperature. (Figure 1a,e,i) High magnification scanning electron microscope (SEM) images clearly reveal morphological changes in the surface as well as the junction between CNFs. (Figure 1b,f,j) The CNF 1200 and CNF 1400 have smooth surface while the CNF 1000 shows a rough surface, which indicates the rearrangement of carbon atoms by the increase of pyrolysis temperature $[28,29]$. The morphological change in the junction between CNFs is also significant. Physically touched interface changes to being merged as an increase of pyrolysis temperature. Figure $1 \mathrm{j}$ clearly shows fused cross junction for CNF 1400. The microstructure of CNF webs was further characterized using the transmission electron microscopy (TEM). Although the CNF 1000 shows a significant contrast in the brightness at the core and shell (Figure 1c), any noticeable difference in the brightness is not observed for both CNF 1200 and CNF 1400 (Figure 1g,k), which is associated with the rearrangement of carbon atoms at the surface. Figure 1d,h,i show the high resolution (HR) TEM images for CNF webs. An increase in pyrolysis temperature results in a transformation of the amorphous and disordered structure into the high ordered and large graphitic structure. These structural and morphological differences in the CNFs, such as graphitization degree and in junction interface, significantly affect the electrical property. The CNF 1000, 1200 and 1400 exhibit sheet resistances of 15.3, 9.6 and $5.0 \mathrm{ohm} / \mathrm{sq}$ (Figure S1).
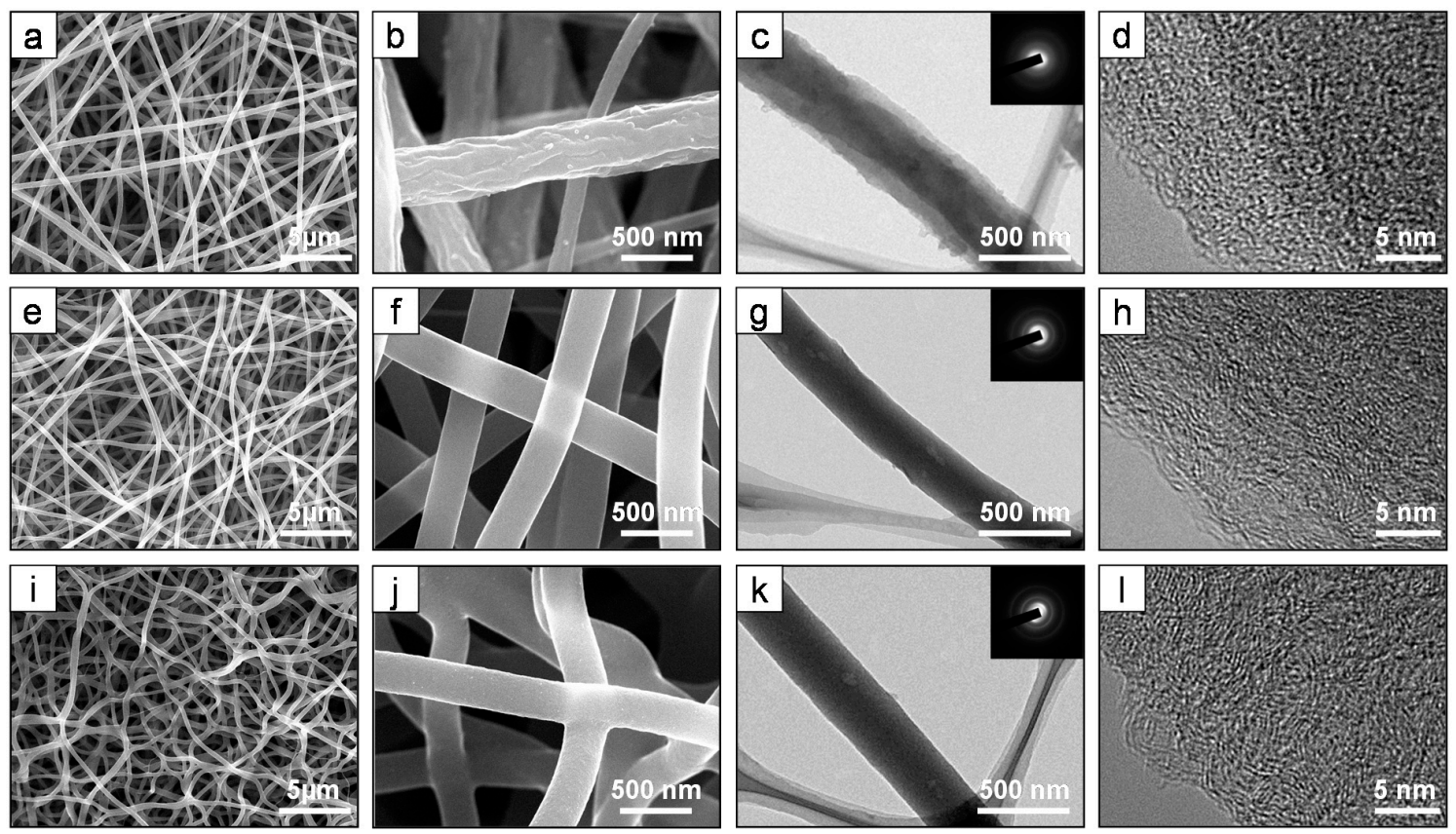

Figure 1. Electron microscope images of carbon nanofibers (CNF) 1000, CNF 1200 and CNF 1400. (a,b) SEM and TEM images of (a-d) CNF 1000, (e-h) CNF 1200, and (i-1) CNF 1400.

X-ray diffraction (XRD), Raman spectroscopy and X-ray photoelectron spectroscopy (XPS) were employed to investigate the physicochemical properties of CNF webs. XRD patterns of CNF webs are shown in Figure 2a. The diffraction peak around the $2 \theta$ angle of $25^{\circ} \sim 26^{\circ}$ is attributed to 
the (002) crystallographic plane of graphite crystallite. The intensity and sharpness of this peak gradually increased with the pyrolysis temperature. Figure $2 b$ shows the Raman spectra for CNF webs. Two dominant peaks are observed at the $\sim 1340 \mathrm{~cm}^{-1}$ and $\sim 1580 \mathrm{~cm}^{-1}$, which are assigned to D-band and G-band, respectively. The intensity ratio of $\mathrm{D}$ band to $\mathrm{G}$ band $\left(\mathrm{I}_{\mathrm{D}} / \mathrm{I}_{\mathrm{G}}\right.$ ) of the $\mathrm{CNF}$ webs decreases with an increase of the pyrolysis temperature, which clearly implies an enhancement in the graphitization degree. The high-resolution C1s spectra of XPS for CNF webs are shown in Figure 2c. Although all CNF webs have the highest intensities at $284.6 \mathrm{eV}$, the full width at half maximum (FWHM) for C1s spectra depends on their pyrolysis temperature. The CNF 1000, 1200 and 1400 have the FWHM values of 1.5, 1.4 and $1.2 \mathrm{eV}$, respectively, which indicates CNF 1400 has the highest graphitization degree among CNF webs. In O1s spectra (Figure 2d), both CNF 1200 and CNF 1400 exhibit more symmetric and narrow spectra towards higher binding energy than those of $\mathrm{CNF}$ 1000 , which implies a decrease in the relative proportion of $\mathrm{C}=\mathrm{O}$ and $\mathrm{C}-\mathrm{OH}$ groups. The $\mathrm{CNF} 1200$ and 1400 do not show any noticeable N1s related peak while the obvious N1s related peak is observed in CNF 1000 (Figure S2). The N1s related peak in CNF 1000 reveals the presence of nitrogen atom from polyacrylonitrile (PAN). The $\mathrm{N}$ atoms might be related to the high $\mathrm{I}_{\mathrm{D}} / \mathrm{I}_{\mathrm{G}}$ intensity in the Raman result and low electronic conductivity [30,31].
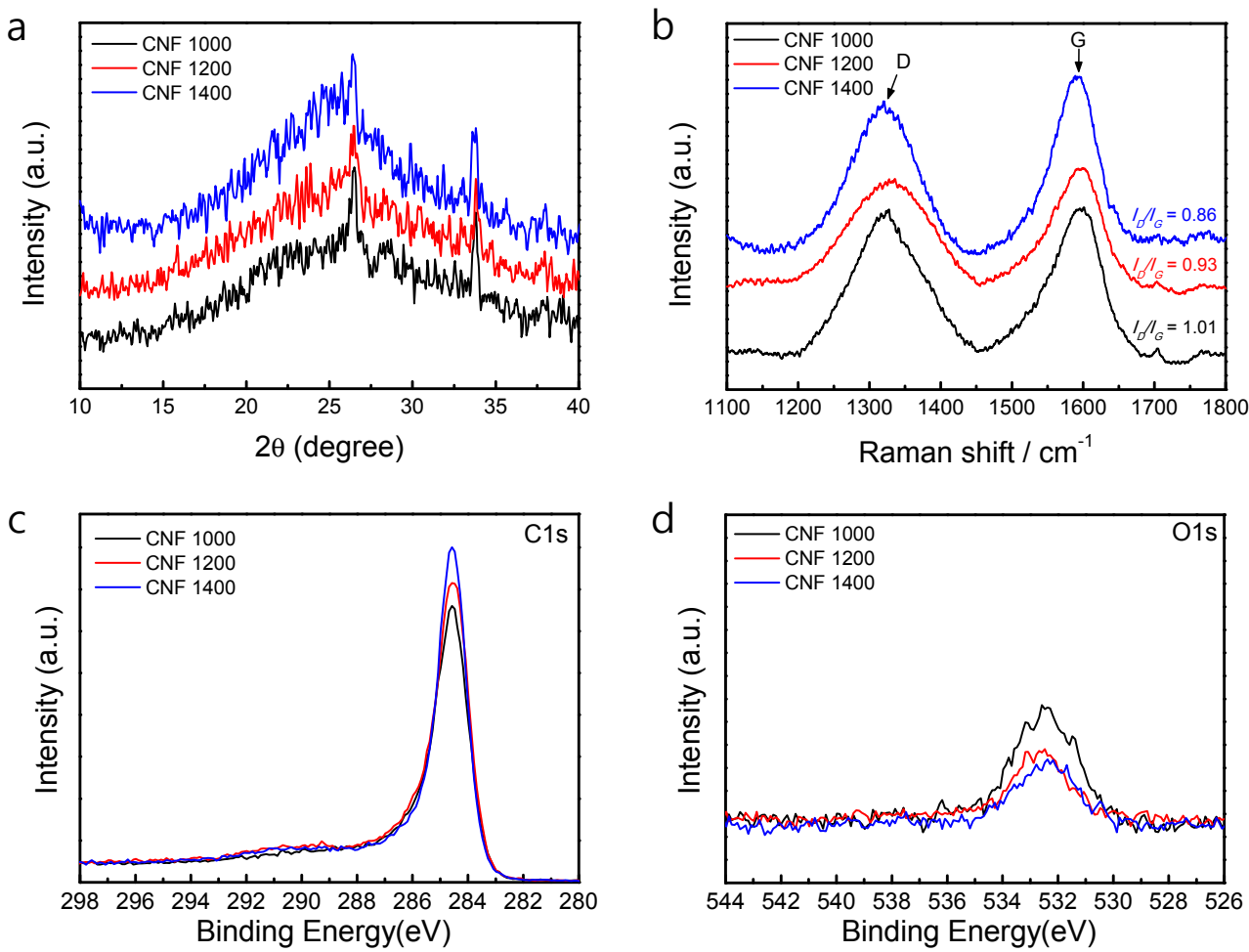

Figure 2. Analysis of CNF 1000, 1200 and 1400 of (a) XRD patterns, (b) Raman results, XPS analysis (c) $\mathrm{C} 1 \mathrm{~s}$ and (d) $\mathrm{O} 1 \mathrm{~s}$.

Figure 3 shows the voltage profiles and cycle performances for CNF 1000, CNF 1200 and CNF 1400 electrodes. The electrochemical properties were evaluated with a limited capacity of $1000 \mathrm{mAh} / \mathrm{g}$ at a current density of $50 \mathrm{~mA} / \mathrm{g}_{c}$ using $1 \mathrm{M} \mathrm{LiPF}_{6} /$ tetra(ethylene glycol)dimethyl ether (TEGDME) as an electrolyte. As shown in Figure 3a, the CNF electrodes show the different shape in the voltage profiles depending on the pyrolysis temperature. The CNF 1000 electrode has the discharge plateau at the voltage of $\sim 2.63 \mathrm{~V}$ and the charge plateau at the voltage of $\sim 4.19 \mathrm{~V}$ at 1 st cycle, respectively, resulting in a large polarization of $\sim 1.56 \mathrm{~V}$. It is observed that the steep potential drop during the ORR and the significant increase in the OER potential after the first cycle. Although the CNF 1200 electrode shows the consistent voltage profile during the cycling, it exhibits also large polarization. On the 
other hand, the CNF 1400 electrode has small polarization of $\sim 1.16 \mathrm{~V}$ with OER potential under $4 \mathrm{~V}$, which leads to the improvement in cycle performance. The CNF electrodes exhibit markedly different cycle performances. (Figure 3d-f) The CNF 1000 electrode works only for 5 cycles. Even though the CNF 1200 electrode exhibits slightly enhanced cycle performance compared to that of the CNF 1000 electrode, it also shows fast degradation after 9 cycles. On the other hand, the CNF 1400 electrode exhibits the stable cyclability for 50 cycles. The enhanced cyclability of the CNF 1400 electrode is attributed to the high graphitization degree, confirmed by the TEM in Figure 1, and reduced defects on the surface. In Table 1 , the $\mathrm{Li}_{-} \mathrm{O}_{2}$ batteries performances of various carbon electrodes are summarized. The charge and discharge voltage (V) difference of CNF webs pyrolyzed at 1000,1200 , and $1400{ }^{\circ} \mathrm{C}$ are lower than the other carbon electrodes [7,13,32-39].
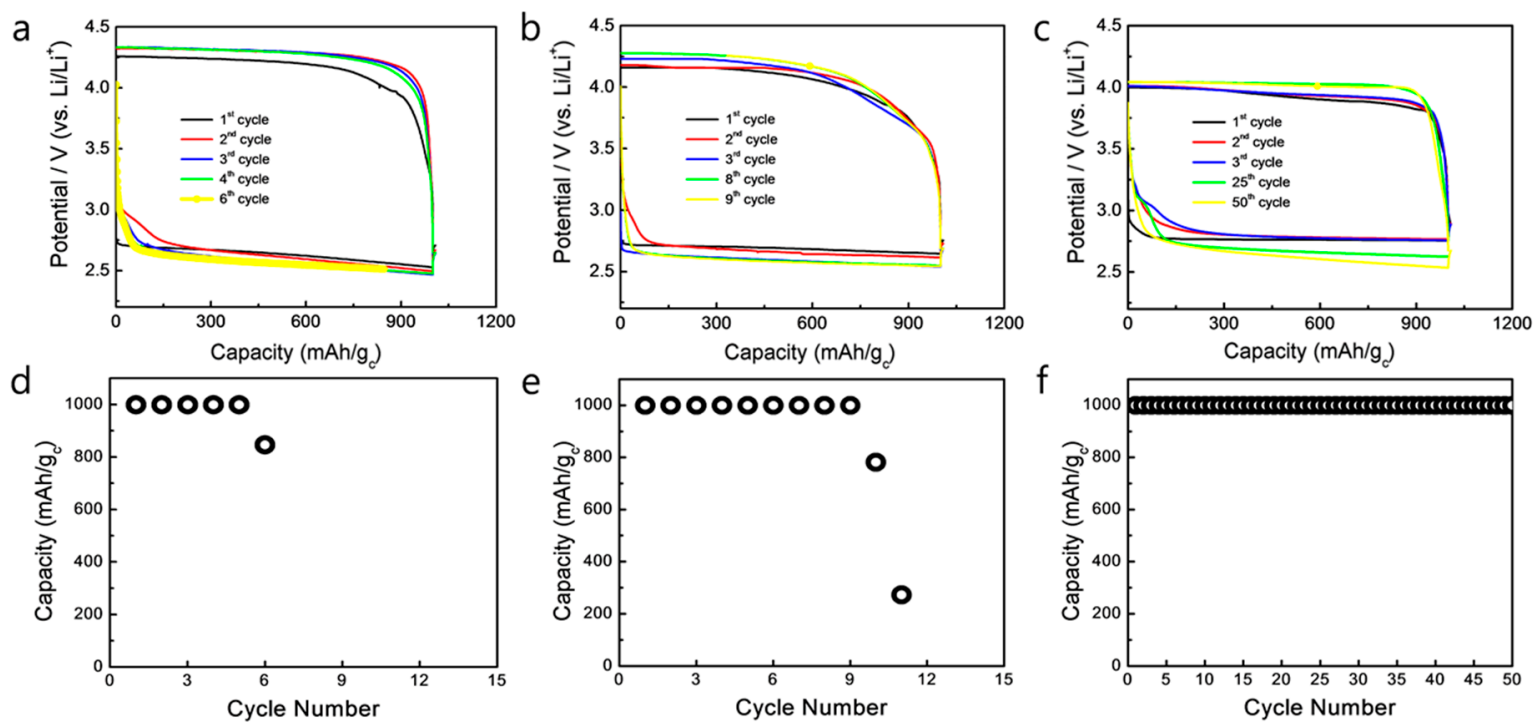

Figure 3. Electrochmical properties of CNF electrodes. Voltage profiles of (a) CNF 1000, (b) CNF 1200 and (c) CNF 1400. Cycle performances of (d) CNF 1000, (e) CNF 1200, and (f) CNF 1400.

Table 1. Some typical achievements for lithium oxygen cells in cathode materials, electrolytes, difference of charge and discharge voltage, and current density.

\begin{tabular}{|c|c|c|c|c|c|}
\hline $\begin{array}{l}\text { Carbon Materials (for } \\
\text { Oxygen Electrode) }\end{array}$ & Electrolyte & $\begin{array}{c}\text { Differences of } \\
\text { Change and } \\
\text { Discharge Viltage (V) }\end{array}$ & Curremt Desity & $\begin{array}{l}\text { Capacity } \\
\left.\text { (mAhg-c }^{-1}\right)\end{array}$ & Ref. \\
\hline Super $\mathrm{P}$ carbon $+\alpha-\mathrm{MnO}_{2}$ & $\mathrm{LiPF}_{6}-\mathrm{PC}$ & 1.3 & $70 \mathrm{mAhg}^{-1}$ & 1000 & [32] \\
\hline $\begin{array}{l}\text { Chevlon carbon }+ \\
\text { Co-phthalocyanine }\end{array}$ & $\mathrm{LiPF}_{6}-\mathrm{PC}-\mathrm{EC}-\mathrm{PAN}$ & 0.92 & $\begin{array}{c}0.1 \mathrm{mAcm}^{-2} \text { (discharge) } \\
0.05 \mathrm{mAcm}^{-2} \text { (charge) }\end{array}$ & 520 & [33] \\
\hline Super $\mathrm{P}$ carbon $+\mathrm{MnO}_{2}$ & LiTFSi-PC & 1.8 & $0.02 \mathrm{mAhg}_{-\mathrm{c}^{-1}}$ & 800 & [34] \\
\hline $\mathrm{BP} 2000$ carbon $+\mathrm{MnO}_{2}$ & $\mathrm{LiPF}_{6}$-TEGDME & 1.4 & 0.13 mAhg-c $^{-1}$ & 800 & [35] \\
\hline Super P carbon & $\mathrm{LiPF}_{6}-\mathrm{TEGDME}$ & 1.8 & $70 \mathrm{mAhg}^{-1} \mathrm{c}^{-1}$ & 3000 & [36] \\
\hline Carbon on carbon paper & $\mathrm{LiCF}_{2} \mathrm{SO}_{2}$-TEGEME & 1.7 & 500 mAhg-c $^{-1}$ & 3000 & [37] \\
\hline CNT fibril & TEGEME & 1.6 & 2000 mAhg-c $^{-1}$ & 1000 & [38] \\
\hline All carbon-nanofiber & $\mathrm{LiPF}_{6}-\mathrm{EC}: \mathrm{DMC}$ & $\sim 1.55$ & $43 \mathrm{mAhg}^{-\mathrm{c}^{-1}}$ & -5000 & [7] \\
\hline Graphene nanosheets & $\mathrm{LiClO}_{4}-\mathrm{PC}$ & 1.22 & 0.1 mAhg-c $^{-1}$ & 2332 & [13] \\
\hline $\begin{array}{l}\text { Porous graphene } \\
\text { nanoarchitectures }\end{array}$ & DMSO & 1.579 & 200 mAhg-c $^{-1}$ & 29,375 & [39] \\
\hline CHF 1000 (this work) & LiTFSi-TEGEME & 1.58 & 50 mAhg-c $^{-1}$ & 1000 & \\
\hline CHF 1000 (this work) & LiTFSi-TEGEME & 1.42 & $50{\mathrm{mAhg}-\mathrm{c}^{-1}}^{-1}$ & 1000 & \\
\hline CHF 1000 (this work) & LiTFSi-TEGEME & 1.16 & $50 \mathrm{mAhg}^{-1}$ & 1000 & \\
\hline
\end{tabular}

The morphological changes of the CNF webs were carefully monitored after the discharging and charging within a limited capacity of $1000 \mathrm{mAh} / \mathrm{g}$. As shown in Figure $4 \mathrm{a}, \mathrm{b}, \mathrm{e}, \mathrm{f}, \mathrm{i}, \mathrm{j}$, , the discharging products were homogeneously formed on the surfaces of all CNF electrodes without any blocking and clogging. In the case of the CNF 1000 electrode, the diameter of discharging product is several 
tens of nanometer. However, it is observed that CNF 1200 and CNF 1400 electrodes have bigger discharging products (200-400 nm diameters) with a bead-like shape than that of CNF 1000 electrode. These results suggest that the formation mechanism of lithium peroxide could be greatly affected by the graphitization degree and surface defect of carbon cathode. After charging, the noticeable discharging product was not observed in all CNF electrodes, which indicates that discharge products $\mathrm{Li}_{2} \mathrm{O}_{2}$ were totally decomposed.
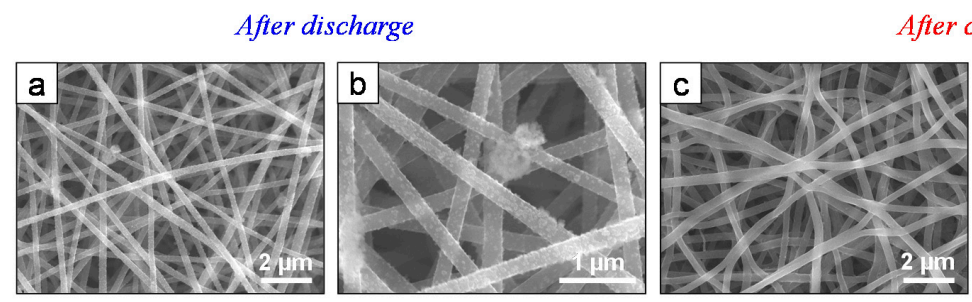

After charge
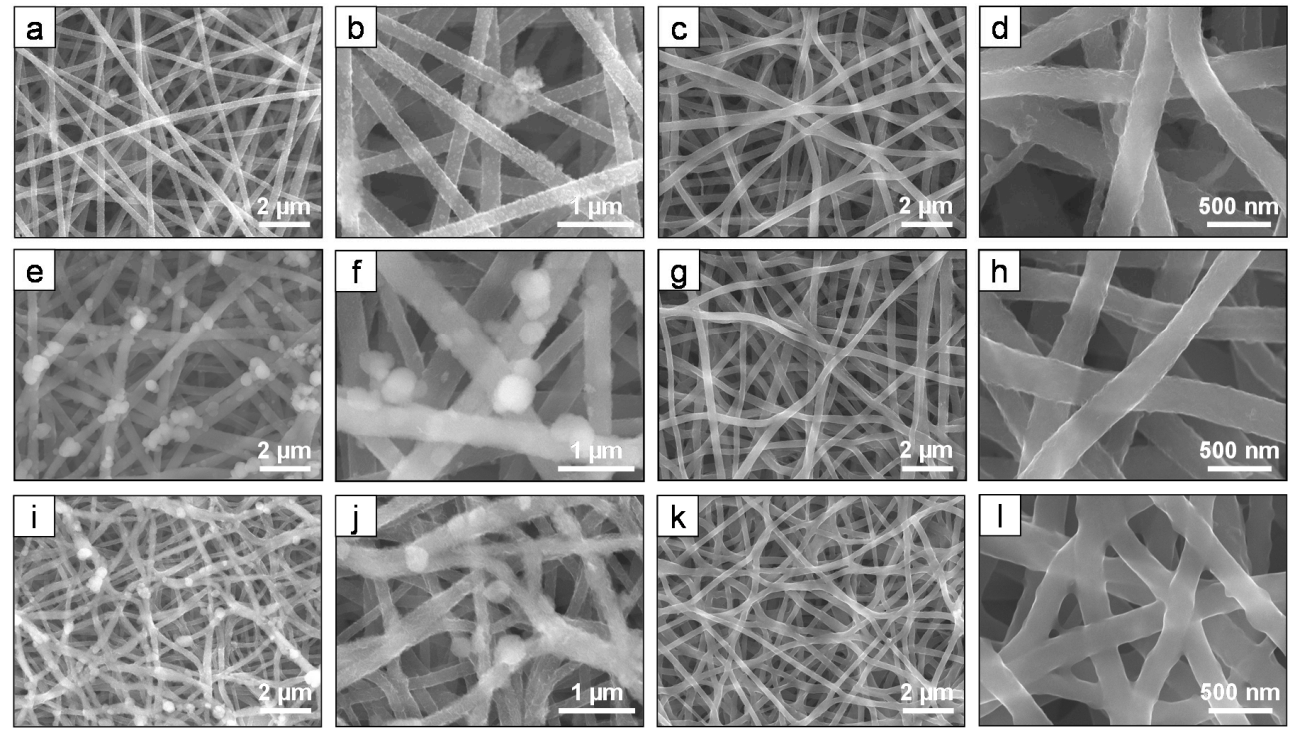

Figure 4. Electron microscope images of (a-d) CNF 1000, (e-h) CNF 1200 and (i-l) CNF 1400 after the discharging and charging.

The morphological change of CNF electrodes after the fully discharging (cut-off voltage: $2.3 \mathrm{~V}$ ) was further investigated (Figure S3). The toroidal shaped lithium peroxides formed on the surface of CNF electrodes without clogging even after full discharge, as shown in Figure S3. Interestingly, the $\mathrm{CNF}$ electrodes show the different $\mathrm{Li}_{2} \mathrm{O}_{2}$ morphology as a function of the pyrolysis temperature. The CNF 1000 electrode with low graphitization degree and many defects shows film like $\mathrm{Li}_{2} \mathrm{O}_{2}$ formation with small beads of $\sim 200 \mathrm{~nm}$. In contrast, CNF 1200 and 1400 electrodes with higher graphitization and lower defect amount compared to CNF 1000 favor large toroidal $\mathrm{Li}_{2} \mathrm{O}_{2}$ with $500 \mathrm{~nm}$ and $1 \mu \mathrm{m}$, respectively. These results imply that the graphitization degree and functional groups on the surface play important roles for the formation shape of $\mathrm{Li}_{2} \mathrm{O}_{2}$. Previous reports represented that the current density effects on the morphology evolution of the discharge product [21,40-42]. Our results suggest further study is required to understand the dominant factors governing the shape of discharge product, which is critical to improve the electrochemical properties of $\mathrm{Li}-\mathrm{O}_{2}$ batteries including the rate capability, polarization and round-trip efficiency.

Figure 5 shows $\mathrm{X}$-ray diffraction (XRD) of the CNF electrodes after discharging and the Raman results of the CNF electrode after 1 cycle. The XRD results of CNF electrodes in Figure 5a reveal the formation of lithium peroxide $\left(\mathrm{Li}_{2} \mathrm{O}_{2}\right)$ without $\mathrm{Li}_{2} \mathrm{O}$ and $\mathrm{LiOH}[7,43]$. The $\mathrm{Li}_{2} \mathrm{Co}_{3}$ of byproducts peak observed from XRD pattern [44,45]. In the Raman spectra (Figure 5b), the intensity ratios of the D-band to the G-band for CNF electrodes after 1 cycle increase significantly compared to those of pristine CNF electrodes. The $\mathrm{I}_{\mathrm{D}} / \mathrm{I}_{\mathrm{G}}$ of CNF 1000 electrode after 1 cycle is 1.6 , which is $64.9 \%$ and $55.3 \%$ higher than those of CNF $1200\left(\mathrm{I}_{\mathrm{D}} / \mathrm{I}_{\mathrm{G}} \sim 1.03\right)$ and $1400\left(\mathrm{I}_{\mathrm{D}} / \mathrm{I}_{\mathrm{G}} \sim 0.97\right)$ electrodes after 1 cycle. The intensity ratio of $\mathrm{I}_{\mathrm{D}} / \mathrm{I}_{\mathrm{G}}$ of the $\mathrm{CNF}$ webs after 1 cycle show similar trend to those of the pristine CNF webs. And notably, the values of $\mathrm{I}_{\mathrm{D}} / \mathrm{I}_{\mathrm{G}}$ of the CNF webs after 1 cycle are increased compared those of pristine CNF webs, which results from increasing defectivity after the electrochemical cycling [46]. 

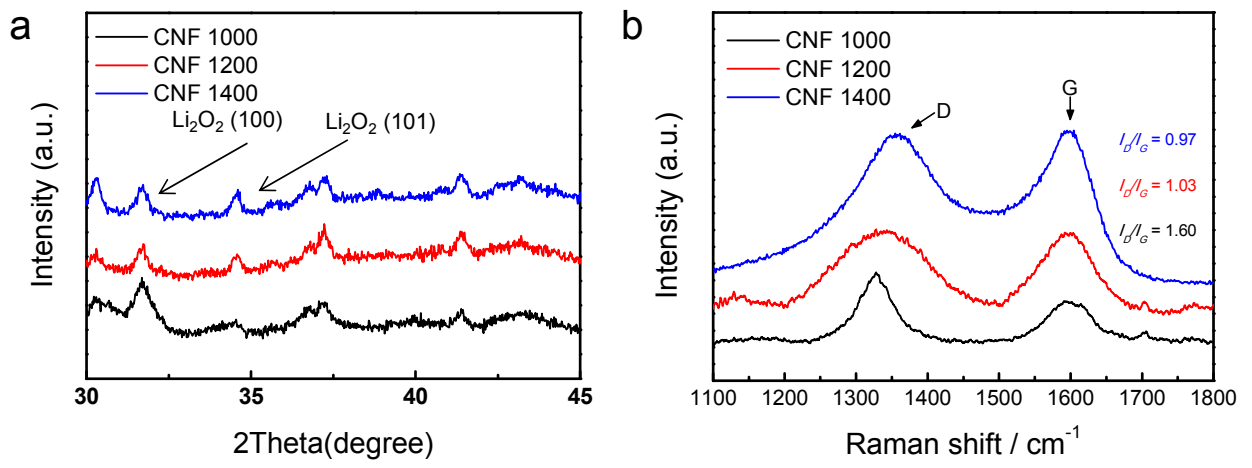

Figure 5. Analysis of CNF 1000, 1200 and 1400 after the discharging (a) XRD patterns (b) Raman results.

\section{Conclusions}

We have explored the graphitization effect of the carbon based electrode on the performances of $\mathrm{Li}-\mathrm{O}_{2}$ batteries through the systematic approach using CNFs prepared by different pyrolysis temperature. The CNFs electrode with high graphitization degree and low surface defects shows lower polarization and improved cyclability compared to those of CNFs electrode with low graphitization degree and high surface defect. Electrochemical properties and analysis results imply that the graphitization degree and surface defect of carbon based air electrode play an important role on the electrochemical properties. We plan to synthesize the highly graphitic carbon nanofibers with metal oxide catalyst, including $\mathrm{Co}_{3} \mathrm{O}_{4}, \mathrm{MnO}_{2}, \mathrm{NiO}, \mathrm{RuO}_{2}$, etc., as a cathode electrode for $\mathrm{Li}-\mathrm{O}_{2}$ batteries and evaluate their electrochemical properties in future research. Further study on the relationship between physicochemical properties of carbon electrode and its electrochemical properties should be carried out to understand the fundamental insight.

Supplementary Materials: The following are available online at http:/ /www.mdpi.com/2076-3417/8/2/209/s1, Table S1: Some typical achievements for lithium oxygen cells in cathode materials, electrolytes, difference of charge and discharge voltage, and current density, Figure S1: Sheet resistance of CNF 1000, CNF 1200 and CNF 1400, Figure S2: XPS analysis N1s of CNF 1000, 1200 and 1400, Figure S3. Voltage profile and SEM images of (a, b and c) CNF 1000, (d, e and f) CNF 1200 and (g, h and i) CNF 1400 after fully discharging.

Acknowledgments: This work was supported by the Korea Institute of Energy Technology Evaluation and Planning (KETEP) and the Ministry of Trade, Industry \& Energy (MOTIE) of the Korea (20174010201240) and by Basic Science Research Program through the National Research Foundation of Korea (NRF) funded by the Ministry of Science, ICT (2016R1C1B2007299).

Author Contributions: H.H. and T.S. designed and performed experiments, analyzed data and wrote the paper; Y.J. and Z.L. designed and performed experiments.

Conflicts of Interest: The authors declare no conflict of interest.

\section{References}

1. Lu, Y.C.; Gallant, B.M.; Kwabi, D.G.; Harding, J.R.; Mitchell, R.R.; Whittingham, M.S.; Shao-Horn, Y. Lithium-oxygen batteries: Bridging mechanistic understanding and battery performance. Energy Environ. Sci. 2013, 6, 750-768. [CrossRef]

2. Li, F.J.; Zhang, T.; Zhou, H.S. Challenges of non-aqueous $\mathrm{Li}_{-} \mathrm{O}_{2}$ batteries: Electrolytes, catalysts, and anodes. Energy Environ. Sci. 2013, 6, 1125-1141. [CrossRef]

3. Jung, H.G.; Kim, H.S.; Park, J.B.; Oh, I.H.; Hassoun, J.; Yoon, C.S.; Scrosati, B.; Sun, Y.K. A Transmission Electron Microscopy Study of the Electrochemical Process of Lithium-Oxygen Cells. Nano Lett. 2012, 12, 4333-4335. [CrossRef] [PubMed]

4. Lim, H.K.; Lim, H.D.; Park, K.Y.; Seo, D.H.; Gwon, H.; Hong, J.; Goddard, W.A.; Kim, H.; Kang, K. Toward a Lithium-“Air" Battery: The Effect of $\mathrm{CO}_{2}$ on the Chemistry of a Lithium-Oxygen Cell. J. Am. Chem. Soc. 2013, 135, 9733-9742. [CrossRef] [PubMed] 
5. Black, R.; Lee, J.H.; Adams, B.; Mims, C.A.; Nazar, L.F. The Role of Catalysts and Peroxide Oxidation in Lithium-Oxygen Batteries. Angew. Chem.-Int. Ed. 2013, 52, 392-396. [CrossRef] [PubMed]

6. Armand, M.; Tarascon, J.M. Building better batteries. Nature 2008, 451, 652-657. [CrossRef] [PubMed]

7. Mitchell, R.R.; Gallant, B.M.; Thompson, C.V.; Shao-Horn, Y. All-carbon-nanofiber electrodes for high-energy rechargeable $\mathrm{Li}_{2} \mathrm{O}_{2}$ batteries. Energy Environ. Sci. 2011, 4, 2952-2958. [CrossRef]

8. Xiao, J.; Mei, D.H.; Li, X.L.; Xu, W.; Wang, D.Y.; Graff, G.L.; Bennett, W.D.; Nie, Z.M.; Saraf, L.V.; Aksay, I.A.; et al. Hierarchically Porous Graphene as a Lithium-Air Battery Electrode. Nano Lett. 2011, 11, 5071-5078. [CrossRef] [PubMed]

9. Itkis, D.M.; Semenenko, D.A.; Kataev, E.Y.; Belova, A.I.; Neudachina, V.S.; Sirotina, A.P.; Havecker, M.; Teschner, D.; Knop-Gericke, A.; Dudin, P.; et al. Reactivity of Carbon in Lithium-Oxygen Battery Positive Electrodes. Nano Lett. 2013, 13, 4697-4701. [CrossRef] [PubMed]

10. Oh, S.H.; Black, R.; Pomerantseva, E.; Lee, J.H.; Nazar, L.F. Synthesis of a metallic mesoporous pyrochlore as a catalyst for lithium- $\mathrm{O}_{2}$ batteries. Nat. Chem. 2012, 4, 1004-1010. [CrossRef] [PubMed]

11. Black, R.; Adams, B.; Nazar, L.F. Non-Aqueous and Hybrid $\mathrm{Li}_{2} \mathrm{O}_{2}$ Batteries. Adv. Energy Mater. 2012, 2, 801-815. [CrossRef]

12. Lee, J.H.; Black, R.; Popov, G.; Pomerantseva, E.; Nan, F.H.; Botton, G.A.; Nazar, L.F. The role of vacancies and defects in $\mathrm{Na}_{0.44} \mathrm{MnO}_{2}$ nanowire catalysts for lithium-oxygen batteries. Energy Environ. Sci. 2012, 5, 9558-9565. [CrossRef]

13. Sun, B.; Wang, B.; Su, D.W.; Xiao, L.D.; Ahn, H.; Wang, G.X. Graphene nanosheets as cathode catalysts for lithium-air batteries with an enhanced electrochemical performance. Carbon 2012, 50, 727-733. [CrossRef]

14. Laoire, C.O.; Mukerjee, S.; Abraham, K.M.; Plichta, E.J.; Hendrickson, M.A. Influence of Nonaqueous Solvents on the Electrochemistry of Oxygen in the Rechargeable Lithium-Air Battery. J. Phys. Chem. C 2010, 114, 9178-9186. [CrossRef]

15. Zhu, X.J.; Zhu, Y.W.; Murali, S.; Stollers, M.D.; Ruoff, R.S. Nanostructured Reduced Graphene Oxide $/ \mathrm{Fe}_{2} \mathrm{O}_{3}$ Composite as a High-Performance Anode Material for Lithium Ion Batteries. ACS Nano 2011, 5, 3333-3338. [CrossRef] [PubMed]

16. Xu, W.; Xiao, J.; Zhang, J.; Wang, D.Y.; Zhang, J.G. Optimization of Nonaqueous Electrolytes for Primary Lithium/Air Batteries Operated in Ambient Environment. J. Electrochem. Soc. 2009, 156, A773-A779. [CrossRef]

17. Girishkumar, G.; McCloskey, B.; Luntz, A.C.; Swanson, S.; Wilcke, W. Lithium-Air Battery: Promise and Challenges. J. Phys. Chem. Lett. 2010, 1, 2193-2203. [CrossRef]

18. Duke, A.S.; Galhenage, R.P.; Tenney, S.A.; Ammal, S.C.; Heyden, A.; Sutter, P.; Chen, D.A. In Situ Ambient Pressure X-ray Photoelectron Spectroscopy Studies of Methanol Oxidation on Pt(111) and Pt-Re Alloys. J. Phys. Chem. C 2015, 119, 23082-23093. [CrossRef]

19. Padbury, R.; Zhang, X.W. Lithium-oxygen batteries-Limiting factors that affect performance. J. Power Sources 2011, 196, 4436-4444. [CrossRef]

20. Armstrong, A.R.; Holzapfel, M.; Novak, P.; Johnson, C.S.; Kang, S.H.; Thackeray, M.M.; Bruce, P.G. Demonstrating oxygen loss and associated structural reorganization in the lithium battery cathode $\mathrm{Li}\left[\mathrm{Ni}_{0.2} \mathrm{Li}_{0.2} \mathrm{Mn}_{0.6} \mathrm{O}_{2}\right.$. J. Am. Chem. Soc. 2006, 128, 8694-8698. [CrossRef] [PubMed]

21. Xu, J.J.; Wang, Z.L.; Xu, D.; Zhang, L.L.; Zhang, X.B. Tailoring deposition and morphology of discharge products towards high-rate and long-life lithium-oxygen batteries. Nat. Commun. 2013, 4, 2438. [CrossRef] [PubMed]

22. Sun, B.; Munroe, P.; Wang, G.X. Ruthenium nanocrystals as cathode catalysts for lithium-oxygen batteries with a superior performance. Sci. Rep. 2013, 3, 2247. [CrossRef] [PubMed]

23. Xu, J.J.; Xu, D.; Wang, Z.L.; Wang, H.G.; Zhang, L.L.; Zhang, X.B. Synthesis of Perovskite-Based Porous $\mathrm{La}_{0.75} \mathrm{Sr}_{0.25} \mathrm{MnO}_{3}$ Nanotubes as a Highly Efficient Electrocatalyst for Rechargeable LithiumOxygen Batteries. Angew. Chem.-Int. Ed. 2013, 52, 3887-3890. [CrossRef] [PubMed]

24. Lu, Y.C.; Xu, Z.C.; Gasteiger, H.A.; Chen, S.; Hamad-Schifferli, K.; Shao-Horn, Y. Platinum-Gold Nanoparticles: A Highly Active Bifunctional Electrocatalyst for Rechargeable Lithium-Air Batteries. J. Am. Chem. Soc. 2010, 132, 12170-12171. [CrossRef] [PubMed]

25. Wu, Y.; Reddy, M.; Chowdari, B. Ramakrishna, Long-Term Cycling Studies on Electrospun Carbon Nanofibers as Anode Material for Lithium Ion Batteries. ACS Appl. Mater. Interfaces 2013, 5, 12175-12184. [CrossRef] [PubMed] 
26. Wu, Y.; Zhu, P.; Reddy, M.; Chowdari, B.; Ramakrishna, S. Maghemite Nanoparticles on Electrospun CNFs Template as Prospective Lithium-Ion Battery Anode. ACS Appl. Mater. Interfaces 2014, 6, 1951. [CrossRef] [PubMed]

27. Pan, H.J.; Yang, J.M.; Wang, S.P.; Xiong, Z.B.; Cai, W.S.; Liu, J.Y. Facile fabrication of porous carbon nanofibers by electrospun PAN/dimethyl sulfone for capacitive deionization. J. Mater. Chem. A 2015, 3, 13827-13834.

28. Yi, B.; Rajagopalan, R.; Burket, C.L.; Foley, H.C.; Liu, X.M.; Eklund, P.C. High temperature rearrangement of disordered nanoporous carbon at the interface with single wall carbon nanotubes. Carbon 2009, 47, 2303-2309.

29. Qi, X.; Ruan, X.F.; Pan, C.X. Graphitization of solid carbon nanofibers at an unexpectedly low temperature. Mater. Lett. 2007, 61, 4272-4275. [CrossRef]

30. Khai, T.V.; Na, H.G.; Kwak, D.S.; Kwon, Y.J.; Ham, H.; Shim, K.B.; Kim, H.W. Significant enhancement of blue emission and electrical conductivity of N-doped graphene. J. Mater. Chem. 2012, 22, 17992-18003. [CrossRef]

31. Lin, Z.Y.; Waller, G.H.; Liu, Y.; Liu, M.L.; Wong, C.P. Simple preparation of nanoporous few-layer nitrogen-doped graphene for use as an efficient electrocatalyst for oxygen reduction and oxygen evolution reactions. Carbon 2013, 53, 130-136. [CrossRef]

32. Ogasawara, T.; Debart, A.; Holzapfel, M.; Novak, P.; Bruce, P.G. Rechargeable $\mathrm{Li}_{2} \mathrm{O}_{2}$ electrode for lithium batteries. J. Am. Chem. Soc. 2006, 128, 1390-1393. [CrossRef] [PubMed]

33. Abraham, K.M.; Jiang, Z. A polymer electrolyte-based rechargeable lithium/oxygen battery. J. Electrochem. Soc. 1996, 143, 1-5. [CrossRef]

34. Mizuno, F.; Nakanishi, S.; Kotani, Y.; Yokoishi, S.; Iba, H. Rechargeable Li-Air Batteries with Carbonate-Based Liquid Electrolytes. Electrochemistry 2010, 78, 403-405. [CrossRef]

35. Laoire, C.O.; Mukerjee, S.; Plichta, E.J.; Hendrickson, M.A.; Abraham, K.M. Rechargeable Lithium/TEGDME$\mathrm{LiPF}_{6} / \mathrm{O}_{2}$ Battery. J. Electrochem. Soc. 2011, 158, A302-A308. [CrossRef]

36. Carboni, M.; Brutti, S.; Marrani, A.G. Surface Reactivity of a Carbonaceous Cathode in a Lithium Triflate/ Ether Electrolyte-Based Li-O ${ }_{2}$ Cell. ACS Appl. Mater. Interfaces 2015, 7, 21751-21762. [CrossRef] [PubMed]

37. Jung, H.G.; Hassoun, J.; Park, J.B.; Sun, Y.K.; Scrosati, B. An improved high-performance lithium-air battery. Nat. Chem. 2012, 4, 579-585. [CrossRef] [PubMed]

38. Lim, H.D.; Song, H.; Kim, J.; Gwon, H.; Bae, Y.; Park, K.Y.; Hong, J.; Kim, H.; Kim, T.; Kim, Y.H.; et al. Superior Rechargeability and Efficiency of Lithium-Oxygen Batteries: Hierarchical Air Electrode Architecture Combined with a Soluble Catalyst. Angew. Chem.-Int. Ed. 2014, 53, 3926-3931. [CrossRef] [PubMed]

39. Sun, B.; Huang, X.D.; Chen, S.Q.; Munroe, P.; Wang, G.X. Porous Graphene Nanoarchitectures: An Efficient Catalyst for Low Charge-Overpotential, Long Life, and High Capacity Lithium-Oxygen Batteries. Nano Lett. 2014, 14, 3145-3152. [CrossRef] [PubMed]

40. Adams, B.D.; Radtke, C.; Black, R.; Trudeau, M.L.; Zaghib, K.; Nazar, L.F. Current density dependence of peroxide formation in the $\mathrm{Li}_{-} \mathrm{O}_{2}$ battery and its effect on charge. Energy Environ. Sci. 2013, 6, 1772-1778. [CrossRef]

41. Tan, P.; Shi, L.; Shyy, W.; Zhao, T.S. Morphology of the Discharge Product in Non-aqueous Lithium-Oxygen Batteries: Furrowed Toroid Particles Correspond to a Lower Charge Voltage. Energy Technol. 2016, 4, 393-400. [CrossRef]

42. Griffith, L.D.; Sleightholme, A.E.S.; Mansfield, J.F.; Siegel, D.J.; Monroe, C.W. Correlating Li/O 2 Cell Capacity and Product Morphology with Discharge Current. ACS Appl. Mater. Interfaces 2015, 7, 7670-7678. [CrossRef] [PubMed]

43. Hu, Y.X.; Han, X.P.; Cheng, F.Y.; Zhao, Q.; Hu, Z.; Chen, J. Size effect of lithium peroxide on charging performance of $\mathrm{Li}_{-} \mathrm{O}_{2}$ batteries. Nanoscale 2014, 6, 177-180. [PubMed]

44. Zhou, J.; Sui, Z.; Zhu, J.; Li, P.; Chen, D.; Dai, Y.; Yuan, W. Characterization of surface oxygen complexes on carbon nanofibers by TPD, XPS and FT-IR. Carbon 2007, 45, 785.

45. Song, S.; Xu, W.; Zheng, J.; Luo, L.; Engelhard, M.; Bowden, M.; Liu, B.; Wang, C.; Zhang, J. Complete Decomposition of $\mathrm{Li}_{2} \mathrm{CO}_{3}$ in $\mathrm{Li}_{-} \mathrm{O}_{2}$ Batteries Using $\mathrm{Ir} / \mathrm{B} 4 \mathrm{C}$ as Noncarbon-Based Oxygen Electrode. Nano Lett. 2017, 17, 1417. [PubMed]

46. Jaber-Ansari, L.; Puntambekar, K.P.; Tavassol, H.; Yildirim, H.; Kinaci, A.; Kumar, R.; Saldana, S.J.; Gewirth, A.A.; Greeley, J.P.; Chan, M.K.Y.; et al. Defect Evolution in Graphene upon Electrochemical Lithiation. ACS Appl. Mater. Interfaces 2014, 6, 17626-17636. [CrossRef] [PubMed]

(C) 2018 by the authors. Licensee MDPI, Basel, Switzerland. This article is an open access article distributed under the terms and conditions of the Creative Commons Attribution (CC BY) license (http:/ / creativecommons.org/licenses/by/4.0/). 